\title{
Verification and Evaluation of Fungicides Efficacy against Wheat Rust Diseases on Bread Wheat (Triticum aestivum L.) in the Highlands of Bale, Southeastern Ethiopia
}

\author{
Wubishet Alemu, Tamene Mideksa \\ Oromia Agricultural Research Institute, Sinana Agricultural Research Center, \\ Bale-Robe, Ethiopia \\ wubtesema@gmail.com
}

\begin{abstract}
Wheat is one of Ethiopia's most important cereal crops in terms of the area of land allocated, volume produced and the number of farmers engaged in its production. However, the production and productivity of wheat is curtailed by various biotic and abiotic stresses. Among the biotic stresses, wheat yellow rust and stem rust diseases caused by Puccinia striiformis f.sp. tritici and Puccinia graminis f.sp. tritici, respectively are the most feared and wheat production bottlenecks. Field experiment was conducted to verify and evaluate the efficacy of fungicides against wheat rust diseases and recommend for registration. It was conducted at three yellow rust and stem rust hot spot locations, Sinana on-station, Sinana on-farm and Agarfa districts of Bale in 2015 main cropping season. Five different fungicides including the standard check and unsprayed plot were used as a treatment. The experiment was laid out in non-replicated plots at three locations where locations were considered as replica. Fungicide spray treatments significantly reduced both yellow rust and stem rust diseases severity to the lowest level possible over the nil application. However, there was no statistically significant difference ( $p \leq 5 \%$ ) between the test and check fungicides in reducing both yellow rust and stem rust diseases severity. Test fungicides revealed comparable and better level of efficacy on both yellow rust and stem rust diseases severity reduction compared to the standard check. There is highly significant difference $(p \leq 5 \%)$ in biomass yield, grain yield and thousand kernel weight between fungicide treatments and nil application of fungicide. The highest grain yield was obtained from KENCOVE sprayed plots while the lowest from nil application. Newly tested fungicides revealed better grain yield advantage than the standard check fungicide. All fungicide treatments also revealed significant yield advantage than untreated plots. The newly verified fungicides are found to be very effective in controlling both yellow rust and stem rust diseases of wheat and are recommended for registration to control wheat rust diseases (yellow rust and stem rust) as sole or integrated disease management options.
\end{abstract}

Keywords: bread wheat, disease severity, fungicide, Puccinia graminis f.sp. tritici, Puccinia striiformis f.sp. tritici, stem rust, yellow rust.

\section{INTRODUCTION}

Bread wheat (Triticum aestivum L.) is one of the most widely grown and most consumed food crops all over the world. It is the most important crop among the cereals by area planted and is followed in importance by maize (Zea mays L.), barley (Hordeum vulgare L.) and sorghum (Sorghum bicolor L.) (FAO, 2009). Annually, wheat is produced on 224.53 million hectares of land and 672.2 million metric tons of wheat is produced in the world (USDA, 2010). According to this report the world average wheat production is 2.99 tons /ha.

Wheat is one of Ethiopia's most important cereal crops in terms of the area of land allocated, volume produced and the number of farmers engaged in its production. It ranks fourth in area production next to Tef, Maize and Sorghum. About 4.6 million farmers produce 4.2 million tons of wheat across 1.6 million hectares of land with average productivity of 2.45 tons/ha (CSA, 2014). However, the production and productivity of wheat is curtailed by various biotic and abiotic factors. Among the biotic factors, wheat rust diseases are the most feared and wheat production bottlenecks. Southeastern part of Ethiopia, particularly the highlands of Bale, is now becoming hot spot for wheat rusts as new, virulent races evolve and spread to other parts of the country, and to the world as well, where the periodic epidemics cause significant yield losses and reduction. 
Both yellow rust and stem rust of wheat caused by Puccinia striiformis f.sp. tritici and Puccinia graminis f.sp. tritici, respectively are the most important diseases on bread wheat in Ethiopia. Yield loss of up to $71 \%$ was recorded in bread wheat due to yellow rust in Bale highlands (Bekele, 2003; Dereje, 2003). However, in severe cases $100 \%$ yield loss was recorded on the highly susceptible varieties due to yellow rust (CIMMYT, 2010). Stem rust is also the most important and aggressive wheat disease in Bale. Currently, most of popular bread wheat varieties grown in Bale are susceptible to virulent stem rust races, Ug99 (TTKSK) and its derivatives. Moreover, in 2013/14 main cropping season a new stem rust race (TKTTF) was detected on popular bread wheat variety called Digalu (SHA 7/KAUZ/HAR 3116) and caused $100 \%$ yield loss in the primary risk areas. The susceptibility of Digalu is due to the breakdown of the resistance conferred by SrTmp gene carried by it. Resistance sources to rusts are the most preferred diseases management options in wheat. Several efforts were made towards resistant cultivars development in Ethiopia and several bread wheat cultivars with various levels of rust resistance were released for production. However, most of the released bread wheat varieties succumb to either yellow or stem rust soon after their release due to either introduction of exotic races or evolvement of new local races and changes in environmental factors (Wubishet and Chemeda, 2016). Moreover, farmers also like to popularize and keep high yielding susceptible cultivars in production for some years ones they adopt them.

Resistance breeding and chemical options are the two principal methods of wheat rust management strategies implemented in most wheat producing areas of the world. However, chemical options are not well exploited by most of Ethiopian farmers. To cope up with this, several fungicides have been verified, evaluated, registered against rusts and is being used in wheat as sole or integrated rusts management options. Hence, to maximize more number of fungicide options in the market and to identify effective fungicides, frequent verification and evaluation of new fungicides against wheat rust diseases is important to sustain wheat production and productivity. Thus, the objective of this study is to verify and evaluate the efficacy of fungicides against wheat rust diseases and recommend for registration.

\section{MATERials AND MeTHODS}

Bread wheat cultivar Kubsa (HAR 1685), highly susceptible to both yellow rust (Puccinia striiformis f.sp. tritici $\mathrm{W}$ ) and stem rust (Puccinia graminis f.sp. tritici) diseases was planted at three yellow rust and stem rust hot spot locations; Sinana (on-station), Selka (on-farm) and Agarfa districts in Bale highlands in non-replicated plots of $5 \mathrm{~m} \mathrm{x} 5 \mathrm{~m}$, where locations were considered as replica. Seed rate of $150 \mathrm{~kg} / \mathrm{ha}$ and fertilizers rate of N/P2O5 $41 / 46 \mathrm{~kg} / \mathrm{ha}$ were used. The whole rate of fertilizer was applied at planting. Test fungicides, JEBA 25\% EC (Propiconazole $250 \mathrm{~g} / \mathrm{l} \mathrm{EC)}$ ), Paragon $460 \mathrm{EC}$ (Spiroxamine $250 \mathrm{~g} / \mathrm{l}+$ Tebuconazole $167 \mathrm{~g} / \mathrm{l}+$ Triadimenol $43 \mathrm{~g} / \mathrm{l} \mathrm{EC}$ ), ASELLA (Epoxiconazole $187 \mathrm{~g} / \mathrm{l}+$ Thiophanate-methyl $310 \mathrm{~g} / \mathrm{l} \mathrm{SC})$ and KENCOVE (125 g/l Pure Epoxiconazole + $125 \mathrm{~g} / \mathrm{l}$ Pure Carbendazim SC) obtained from different chemical companies were sprayed with the rates of $0.5,0.6,0.5$ and 1 lit/ha, respectively. Recently registered and widely used fungicide Rex Duo (Epoxiconazole $187 \mathrm{~g} / \mathrm{l}+$ Thiophanate-methyl $310 \mathrm{~g} / \mathrm{l} \mathrm{SC}$ ) was included as standard check along with nil application (local check) for comparison. Fungicide treatments were applied at 5\% severity level of yellow rust (booting crop growth stage) and at $2 \%$ severity level of stem rust. Test and check fungicides were applied manually using Knapsack sprayer delivering 250 liter of water/ha. Biomass and grain yield data were determined on the basis of crop harvested from $5 \mathrm{~m}$ x $5 \mathrm{~m}$ harvestable plot area and converted to hectare base. Rust severity was recorded in percentage using modified Cobb Scale (Peterson et al., 1948).

\subsection{Data Analysis}

Analysis of Variance (ANOVA) was done by using SAS GLM Procedure (SAS version 9.00, Inst. 2002) and means comparisons for the significantly different variables were made among treatments using Least Significant Differences (LSD) test at 0.05 levels of significance.

\section{RESULTS AND DISCUSSION}

\subsection{Disease Epidemics}

In 2015/16 main cropping season both yellow/stripe rust and stem rust disease pressure was very high and excellent disease epidemics was developed to the level of creating significant difference among treatments across all test locations in Bale zone. Fungicide spray treatments (test and check 
fungicides) significantly reduced both yellow rust and stem rust diseases severity over the nil application. However, there was no statistically significant difference between the test and check fungicides and among the test fungicides in reducing both yellow rust and stem rust diseases severity (Table 1). Even though there was no statistically significant difference between the test and check fungicides, relatively Rex Duo (standard check fungicide) reduced both yellow and stem rust diseases severity to the lowest level compared to the test fungicides, JEBA 25\% EC and Paragon 460 EC. However, from visual field observation the test fungicides, JEBA 25\% EC and Paragon 460 EC showed comparable level of efficacy in controlling both yellow and stem rust diseases with the standard check, Rex Duo. Paragon 460 EC reduced yellow rust and stem rust diseases severity by about 34.53 and $52.17 \%$, respectively as compared to unsprayed plot. Whereas JEBA $25 \%$ EC reduced yellow rust and stem rust diseases severity by about 36.13 and $53.84 \%$, respectively.

As it is witnessed from table 1, test fungicides, ASELLA and KENCOVE and standard check fungicide Rex Duo significantly reduced both yellow rust and stem rust diseases severity to the lowest level possible over the nil application. However, there was no statistically significant difference between the test and check fungicides in reducing both yellow rust and stem rust diseases severity (Table 1). Even though there was no statistically significant difference between the test and check fungicides and among test fungicides, relatively ASELLA and KENCOVE reduced both yellow and stem rust diseases severity to the lowest level compared to the standard check fungicide, Rex Duo. However, from visual field observation the standard check fungicide, Rex Duo showed comparable efficacy in controlling both yellow and stem rust diseases with the test fungicides, ASELLA and KENCOVE. ASELLA reduced yellow rust and stem rust diseases severity by about 39.27 and $61.67 \%$, respectively as compared to unsprayed plot. Similarly, KENCOVE reduced yellow rust and stem rust diseases severity by about 39.20 and 55.67\%, respectively while the standard check fungicide, Rex Duo reduced yellow rust and stem rust diseases severity by about 37.80 and $54.17 \%$, respectively compared to unsprayed plot.

It is evident from visual field observation and table 1 data analysis result is that the test fungicides, JEBA 25\% EC and Paragon 460 EC showed comparable level of efficacy on both yellow rust and stem rust diseases severity reduction compared to the standard check. Whereas ASELLA and KENCOVE showed better level of efficacy on both yellow rust and stem rust diseases severity reduction compared to the standard check. Therefore, JEBA 25\% EC, Paragon 460 EC, ASELLA and KENCOVE can be recommended for the control of both wheat rust diseases (yellow rust and stem rust).

\subsection{Yield and Yield Components}

The statistical analysis showed that there was no significant difference between the test fungicides and the standard check fungicide in biomass yield, grain yield, thousand kernel weight and hectoliter weight (Table 1). Moreover, there was no significant difference among the test fungicides for the above mentioned agronomic parameters. Even though there was no statistically significant difference in biomass yield, grain yield, thousand kernel weight and hectoliter weight between test fungicides and Rex Duo, relatively higher biomass yield, grain yield, thousand kernel weight and hectoliter weight was obtained from Paragon 460 EC, ASELLA and KENCOVE sprayed treatments but the difference is insignificant to differentiate the effect of the chemicals. There is highly significant difference in biomass yield, grain yield and thousand kernel weight between fungicide treatments (test and check fungicides) and nil application (unsprayed plot). However, there is no significant difference among JEBA 25\% EC, Paragon 460 EC, Rex Duo and unsprayed plots in hectoliter weight. Significant difference in thousand kernel weight was observed between the test fungicides, ASELLA and KENCOVE and nil application. Even though there was no statistical significant difference among treatments, relatively better grain yield was obtained from KENCOVE sprayed plots while the lowest from nil application. All test fungicides revealed better grain yield advantage than the standard check Rex Duo. Test and check fungicides also revealed significant yield advantage over unsprayed plot. Likely, JEBA 25\% EC, Paragon 460 EC, ASELLA, KENCOVE and Rex Duo revealed $1158.50 \mathrm{~kg} / \mathrm{ha}$ (11.59 qt/ha), $1198.60 \mathrm{~kg} / \mathrm{ha}(11.99 \mathrm{qt} / \mathrm{ha}), 1188.60 \mathrm{~kg} / \mathrm{ha}(11.89 \mathrm{qt} / \mathrm{ha}), 1334.30 \mathrm{~kg} / \mathrm{ha}(13.34 \mathrm{qt} / \mathrm{ha})$ and $973.60 \mathrm{~kg} / \mathrm{ha}(9.74 \mathrm{qt} / \mathrm{ha})$ yield advantage over nil application, respectively. 
Table 1. Evaluation of fungicides efficacy against yellow rust and stem rust diseases severity, yield and yield components of bread wheat in Bale highlands during 2015/2016 main cropping season.

\begin{tabular}{|c|c|c|c|c|c|c|c|c|c|}
\hline \multicolumn{2}{|c|}{ Treatments } & \multirow{2}{*}{$\begin{array}{l}\text { Rate } \\
\text { (l/ha) }\end{array}$} & \multirow{2}{*}{$\begin{array}{c}\text { Yellow } \\
\text { rust } \\
\text { severity } \\
(\%)\end{array}$} & \multirow{2}{*}{$\begin{array}{l}\text { Stem rust } \\
\text { severity } \\
(\%)\end{array}$} & \multirow{2}{*}{$\begin{array}{c}\text { PH } \\
(\mathbf{c m})\end{array}$} & \multirow{2}{*}{$\begin{array}{c}\text { Biomass } \\
\text { (t/ha) }\end{array}$} & \multirow{2}{*}{$\begin{array}{c}\text { Grain } \\
\text { yield } \\
\text { (kg/ha) }\end{array}$} & \multirow{2}{*}{$\begin{array}{c}\text { TKW } \\
\text { (g) }\end{array}$} & \multirow[t]{2}{*}{ HLW } \\
\hline Common name & $\begin{array}{l}\text { Trade } \\
\text { name }\end{array}$ & & & & & & & & \\
\hline $\begin{array}{l}\text { Propiconazole } 250 \mathrm{~g} / 1 \\
\text { EC }\end{array}$ & $\begin{array}{l}\text { JEBA } 25 \% \\
\text { EC }\end{array}$ & 0.5 & $3.87^{\mathrm{b}}$ & $12.83^{\mathrm{b}}$ & $84.00^{\mathrm{abc}}$ & $6.87^{\mathrm{a}}$ & $1912.00^{\mathrm{a}}$ & $32.17^{\mathrm{b}}$ & $76.67^{\mathrm{ab}}$ \\
\hline $\begin{array}{l}\text { Spiroxamine } 250 \mathrm{~g} / \mathrm{l}+ \\
\text { Tebuconazole } 167 \mathrm{~g} / \mathrm{l}+ \\
\text { Triadimenol } 43 \mathrm{~g} / \mathrm{l} \mathrm{EC} \\
\end{array}$ & $\begin{array}{l}\text { Paragon } \\
460 \text { EC }\end{array}$ & 0.6 & $5.47^{\mathrm{b}}$ & $14.50^{\mathrm{b}}$ & $89.67^{\mathrm{a}}$ & $7.07^{\mathrm{a}}$ & $1952.10^{\mathrm{a}}$ & $33.53^{\mathrm{b}}$ & $76.93^{\mathrm{ab}}$ \\
\hline $\begin{array}{l}\text { Epoxiconazole } 187 \mathrm{~g} / \mathrm{l}+ \\
\text { Thiophanate-methyl } 310 \\
\mathrm{~g} / \mathrm{l} \mathrm{SC}\end{array}$ & ASELLA & 0.5 & $0.73^{\mathrm{b}}$ & $5.00^{\mathrm{b}}$ & $86.00^{\mathrm{ab}}$ & $6.80^{\mathrm{a}}$ & $1942.10^{\mathrm{a}}$ & $34.33^{\mathrm{ab}}$ & $77.73^{\mathrm{a}}$ \\
\hline $\begin{array}{l}125 \mathrm{~g} / 1 \text { Pure } \\
\text { Epoxiconazole }+125 \mathrm{~g} / 1 \\
\text { Pure Carbendazim SC }\end{array}$ & KENCOVE & 1 & $0.80^{\mathrm{b}}$ & $11.00^{\mathrm{b}}$ & $84.33^{\mathrm{abc}}$ & $7.13^{\mathrm{a}}$ & $2087.80^{\mathrm{a}}$ & $35.87^{\mathrm{a}}$ & $77.47^{\mathrm{a}}$ \\
\hline $\begin{array}{l}\text { Epoxiconazole } 187 \mathrm{~g} / \mathrm{l}+ \\
\text { Thiophanate-methyl } 310 \\
\mathrm{~g} / \mathrm{l} \mathrm{SC}\end{array}$ & Rex Duo & 0.5 & $2.20^{\mathrm{b}}$ & $12.50^{\mathrm{b}}$ & $79.00^{\mathrm{c}}$ & $6.27^{\mathrm{a}}$ & $1727.10^{\mathrm{a}}$ & $32.90^{\mathrm{b}}$ & $72.90^{\mathrm{ab}}$ \\
\hline & Nil & - & $40.00^{\mathrm{a}}$ & $66.67^{\mathrm{a}}$ & $82.67 b^{c}$ & $4.65^{\mathrm{b}}$ & $753.50^{\mathrm{b}}$ & $24.20^{\mathrm{c}}$ & $71.47^{\mathrm{b}}$ \\
\hline \multicolumn{3}{|l|}{ Mean } & 8.84 & 20.42 & 84.28 & 6.46 & 1729.09 & 32.17 & 75.53 \\
\hline \multicolumn{3}{|l|}{ CV (\%) } & 19.08 & 29.5 & 4.05 & 12.78 & 19.62 & 3.86 & 4.28 \\
\hline \multicolumn{3}{|l|}{ LSD (0.05) } & 7.89 & 10.96 & 6.21 & 1.50 & 617.26 & 2.26 & 5.88 \\
\hline
\end{tabular}

$\mathrm{PH}=$ Plant Height, TKW = Thousand Kernel Weight, HLW = Hectoliter Weight, LSD = Least significant difference among treatment means $(\mathrm{p} \leq 5 \%), \mathrm{CV}=$ Coefficient of variation, Means with the same letter within a column are not significantly different.

Fungicide efficacy is based on proper application timing to achieve optimum effectiveness of the fungicide as determined by labeled instructions and overall level of disease in the field at the time of application. Differences in efficacy among fungicide products were determined by direct comparisons among products in field tests and are based on a single application of the labeled rate (Kiersten Wise, 2016). All the current commercial wheat cultivars in East Africa are susceptible to the new wheat rust races and it is not possible to grow a profitable crop of wheat without the application of fungicides (Wanyera et al., 2009). Fungicide tests in Kenya showed 50\% higher yield in the treated versus the untreated plots (Wanyera et al., 2009). Large scale wheat growers in Ethiopia are reported to spend around US $\$ 0.5$ million annually on fungicides (Tadesse et al., 2010). The current study is also clearly shows that in Ethiopia it is not possible to grow susceptible to moderately susceptible wheat varieties without fungicide application in areas where wheat rust diseases is a major problem.

Ordish and Dufour (1969) noted the popularity of spraying fungicides to control crop diseases; returns of up to three times the cost involved often were realized from fungicide application. In the United Kingdom, experiments conducted from 1978 to 1982 showed that applying fungicides to winter wheat resulted in a yield response of up to $89 \%$, and the value of increased yield from fungicide application to cereals in 1982 was nearly double the fungicide costs (Cook and King, 1984). In Denmark, fungicide application to control wheat powdery mildew and Septoria diseases resulted in yield increases of 400-2700 kg ha ${ }^{-1}$ with margin over cost varying from $-500 \mathrm{~kg} \mathrm{ha}^{-1}$ to $2000 \mathrm{~kg} \mathrm{ha}^{-1}$ (Jørgensen et al., 2000). An economic evaluation of fungicide use in winter wheat in Sweden also showed a mean net return of US\$28 ha- ${ }^{1}$ during the period 1995-2007 and \$16 ha ${ }^{-1}$ during the period 1983-2007 (Wiik and Rosenqvist, 2010).

Different studies from different areas have demonstrated yield increases in wheat due to fungicide application. Wegulo et al. (2009) showed that up to $42 \%$ yield loss was prevented by applying foliar fungicides to winter wheat. Kelley (2001) also found that over a period of six years, the fungicide propiconazole significantly increased winter wheat yield by $77 \%$. Vamshidhar et al. (1998) demonstrated significant yield increases from fungicide application to control the disease complex of leaf rust, tan spot, and Septoria tritici blotch in wheat. They found that cultivar specific economic benefits were associated with improved wheat quality from fungicide treatment. Ransom and McMullen (2008) showed that within an environment and across wheat cultivars, fungicides improved yields by 5.5 to $44.0 \%$. Tebuconazole applied at Zadoks growth stage (GS) 37 (Zadoks, 1974) and propiconazole applied at GS 37 followed by triadimefon + mancozeb at GS 55 to control leaf rust and Septoria tritici blotch consistently resulted in the lowest disease severities and highest wheat yields (Milus, 1994). 


\section{Conclusions}

JEBA 25\% EC, Paragon 460 EC, ASELLA and KENCOVE statistically did not differ from the standard check fungicide (Rex Duo) in controlling both wheat yellow rust and stem rust diseases and provided better biomass yield, grain yield, thousand kernel weight and hectoliter weight than Rex Duo sprayed treatments. Moreover, these fungicides reduced both yellow rust and stem rust diseases severity to the lowest level possible and revealed grain yield advantage better than the standard check and nil fungicide application (local check). After all assessment and evaluation result, the newly verified fungicides are found to be very effective in controlling both yellow rust and stem rust diseases of wheat. Thus, JEBA 25\% EC, Paragon 460 EC, ASELLA and KENCOVE are recommended for registration for the control of wheat rust diseases (yellow rust and stem rust) as sole or integrated disease management options on wheat.

\section{ACKNOWLEDGMENTS}

The study was fully funded by Lions International Trading PLC, Crop Save Trading and Issachor Agro Input Importer and Distributor through Oromia Agricultural Research Institute. The author would like to offer a great sense of gratitude for Cereal crops research case team members of Sinana Agricultural Research Center for their technical and professional contributions for the completion of this work.

\section{REFERENCES}

[1] Bekele Hundie. 2003. Short report on stripe rust and stem rust. In Bedada Girma (ed.). Pp.67-68. BADE. 2003. Bale Agricultural Development Enterprise. Proceedings of the Agronomy Workshop. Addis Ababa, Ethiopia.

[2] CIMMYT (International Maize and Wheat Improvement Center). 2010. Serious Outbreaks of Wheat Stripe or Yellow Rust in Ethiopia. Annual Report, Oct 2010.

[3] Cook, R. J. and King, J. E. 1984. Loss caused by cereal diseases and the economics of fungicidal control, Plant Diseases: Infection, Damage and Loss, Blackwell, pp. 237-245, ISBN 0632011262, Oxford, UK.

[4] CSA (Central Statistical Authority). 2014. Agricultural survey sample. Report on area and production of crops (private peasant holding, meher season). Statistical Bulletin No 278. Addis Ababa, Ethiopia.

[5] Dereje Hailu. 2003. Effect of stripe rust (Puccinia striiformis) on yield and yield components and quality of improved bread wheat (Triticum aestivum) varieties. MSc Thesis. Alemaya University.99pp.

[6] FAO (Food and Agriculture Organization of the United Nations). 2009. Wheat Flour. FAO Agribusiness hand book. Rome, Italy. Available at www.eastagri.org.

[7] Jørgensen, L. N., Henriksen, K. E. and Nielsen, G. C. 2000. Margin over cost in disease management in winter wheat and spring barley in Denmark, Brighton Crop Protection Conference: Pests \& Diseases-2000: Volume 2: Proceedings of an International Conference, pp. 655-662, ISBN 1-901396-59-2, Brighton, UK, November 13-16, 2000.

[8] Kelley, K. W. 2001. Planting date and foliar fungicide effects on yield components and grain traits of winter wheat. Agronomy Journal, Vol. 93, No. 2, (March 2001) pp. 380-389, ISSN 0002-1962.

[9] Kiersten, W. 2016. Fungicide Efficacy for Control of Wheat Diseases. Purdue Extension Education Store. Purdue University. Available at www.edustore.purdue.edu.

[10] Milus, E. A. 1994. Effect of foliar fungicides on disease control, yield and test weight of soft red winter wheat. Crop Protection, Vol. 13, No. 4, (February 1994), pp. 291-295 ISSN 0261-2194.

[11] Ordish, G. and Dufour, D. (1969). Economic bases for protection against plant diseases. Annual Review of Phytopathology, Vol. 7, No. 1, (January 1969), pp. 31-50, ISSN 0066-4286

[12] Peterson, R. F., Campbell, A. B. and Hannah, A. E. 1948. A diagrammatic scale for estimating rust intensity of leaves and stem of cereals. Canadian J. Res. Sect. C. 26: 496-500.

[13] Ransom, J. K. and McMullen, M. P. 2008. Yield and disease control on hard winter wheat cultivars with foliar fungicides. Agronomy Journal, Vol. 100, No. 4, (October 2008) pp. 11301137, ISSN 0002-1962. 
[14] Tadesse, K., Amare, A. and Ayele, B. 2010. Effect of fungicide on the development of wheat stem rust and yield of wheat varieties in highlands of Ethiopia. African Crop Science Journal. 18(1):23-33.

[15] USDA (United States Department of Agriculture). 2010. World Agricultural Production.

[16] Circular Series. May 05-10.

[17] Vamshidhar, P., Herrman, T. J., Bockus, W. W. and Loughin, T. M. (1998). Quality response of twelve hard red winter wheat cultivars to foliar disease across four locations in central Kansas. Cereal Chemistry, Vol. 75 No. 1 (January 1998 ), pp. 94-99, ISSN 0009-0352.

[18] Wanyera, R., Macharia, J. K., Kilonzo, S. M. and Kamundia, J. W. 2009. Foliar fungicides to control wheat stem rust, race TTKS (Ug99), in Kenya. Plant Disease. September: 929.

[19] Wegulo, S. N., Breathnach, J. A. and Baenziger, P. S. 2009. Effect of growth stage on the relationship between tan spot and spot blotch severity and yield in winter wheat. Crop Protection, Vol. 28, No. 8, (May 2009), pp. 696-702, ISSN 0261-2194.

[20] Wiik, L. and Rosenqvist, H. (2010). The economics of fungicide use in winter wheat in southern Sweden. Crop Protection, Vol. 29, No. 1, (January 2010), pp. 11-19, ISSN 0261-2194.

[21] Wubishet Alemu and Chemeda Fininsa. 2016. Effects of Environment on Wheat Varieties' Yellow Rust Resistance, Yield and Yield Related Traits in South-Eastern Ethiopia. Science publishing group. Plant. 4(3): 14-22. 